2. To: (Receiving Organization)

Distribution

5. Proj:/Prog./Dept./Div.:

HANDI 2000 INTEGRATION

8. Originator Remarks:

FOR REIEASE

11A. Design Baseline Document?
Ges No

4. Related EDT No::

$\mathrm{N} / \mathrm{A}$

7. Purchase Order No.:

$\mathrm{N} / \mathrm{A}$

9. Equip./Component No:

$\mathrm{N} / \mathrm{A}$

10. System/BIdg./Facility:

$\mathrm{N} / \mathrm{A}$

12. Major Assm. Dwg. No.:

$\mathrm{N} / \mathrm{A}$

13. Permit/Permit Application No.:

$\mathrm{N} / \mathrm{A}$

14. Required Response Date:

$\mathrm{N} / \mathrm{A}$

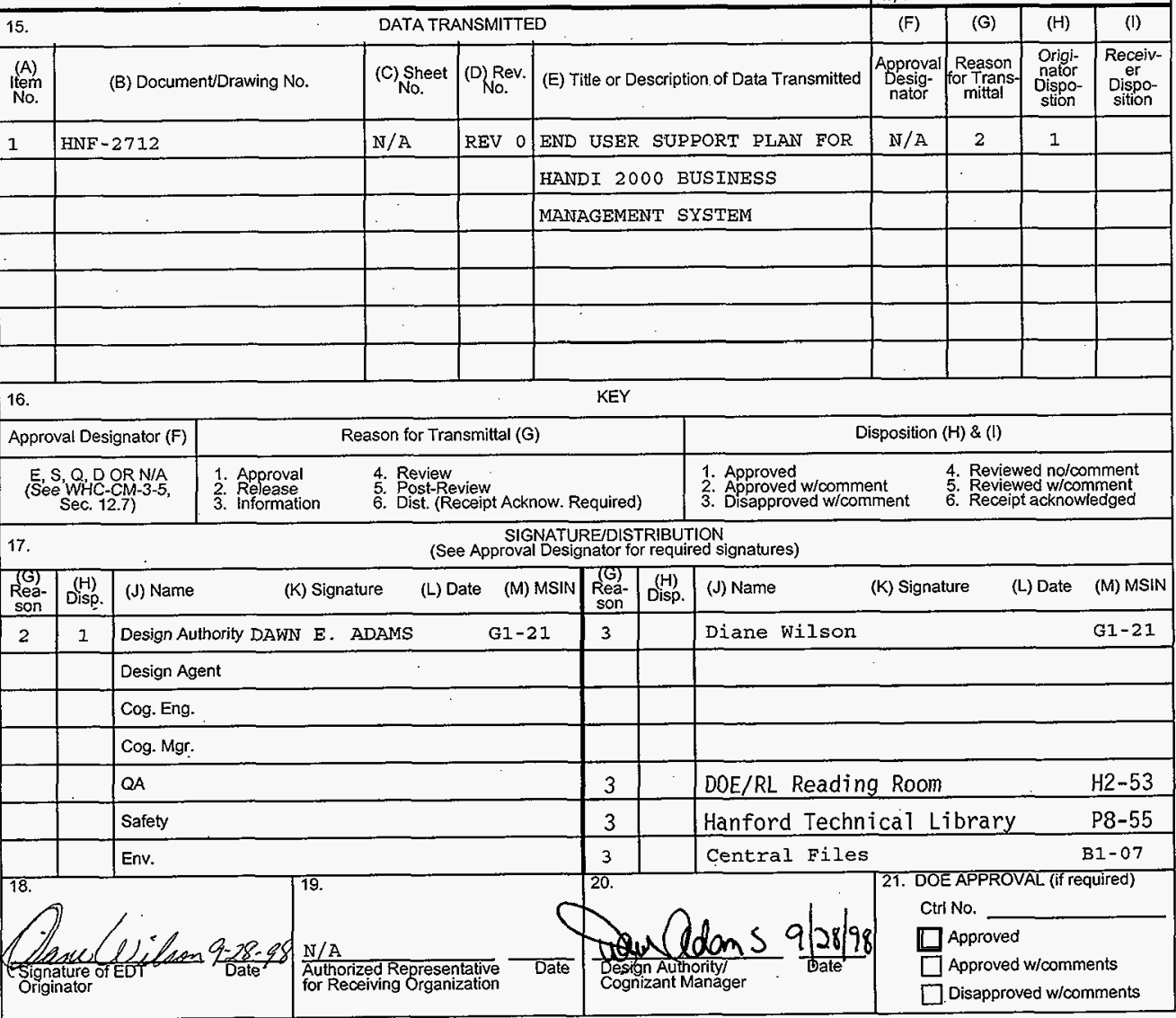

BD-7400-172-1

Systems
FDH
6. Design Authority/Design Agent/Cog. Engr.:
DAWN E. ADAMS




\section{END USER SUPPORT PLAN FOR HANDI 2000 BUSINESS MANAGEMENT SYSTEM}

Dawn E. Adams, FDH

2355 Stevens MSN G1-21

Richland, WA 99352

U.S. Department of Energy Contract DE-AC06-96RL13200

EDT/ECN: 625362

Org Code: SL610000

B\&R Code: EW7001000
UC: 900

Charge Code: HANF 6800

Total Pages: 24

Key Words: HANDI 2000, BUSINESS MANAGEMENT, END USER SUPPORT,H2K, BMS, PEOPLESOFT, PASSPORT

Abstract: Primary objective of the END USER SUPPORT PLAN is to ensure that the end users have access that is reasonable and commensurate with job position functionality in order to perform their work effectively. Another objective is to ensure user support is provided to utilize the new BMS while minimizing significant security risks to BMS. The EUSP becomes effective as of this document's acceptance and will provide guidance through implementation efforts and as a "living document" ...

TRADEMARK DISCLAIMER. Reference herein to any specific commercial product, process, or service by trade name, trademark, manufacturer, or otherwise, does not necessarily constitute or imply its endorsement, recommendation, or favoring by the United States Government or any agency thereof or its contractors or subcontractors.

Printed in the United States of America. To obtain copies of this document, contact: Document Control Services, P.O. Box 950, Mailstop H6-08, Richland WA 99352, Phone (509) 372-2420; Fax (509) 376-4989.

PassPort (PP) is a trademark of Indus Corporation. Peoplesoft (PS) is a trademark of Peoplesoft Corporation. Windows 95 is a trademark of Microsoft Corporation.

Primavera (P3) is a trademark of Primavera
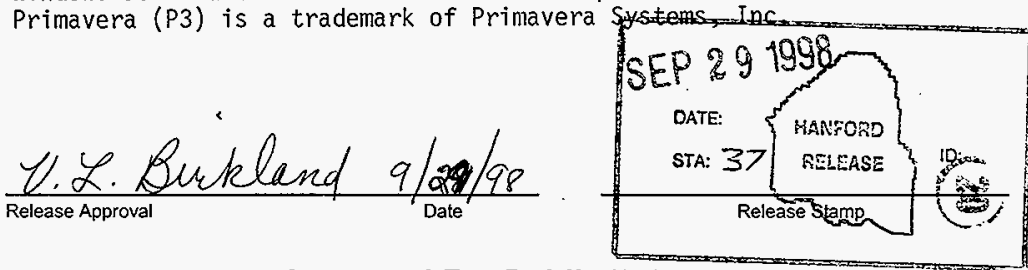

\section{Approved For Public Release}




\section{END USER SUPPORT PLAN}

FOR

HANDI 2000

\section{BUSINESS MANAGEMENT SYSTEM}

Prepared by: Amanda McKay, LMSI Software Engineer

Prepared for: Fluor Daniel Hanford

Approved by:

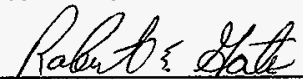

Robert E. Gates, H2K Project Director

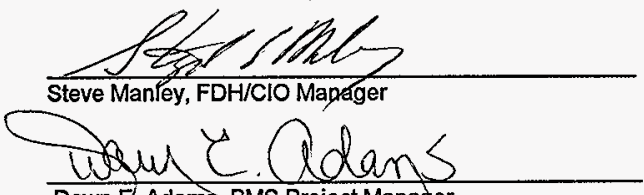

Dawn E. Adams, BMS Project Manager

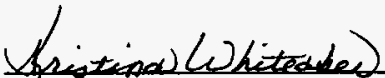

Kristina Whiteaker, INDUS Project Manager

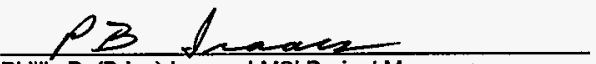

Phillip B. (Brian) Isaacs, LMSI Project Manager
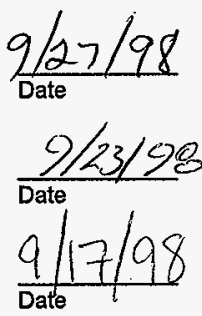

\section{$\frac{9 / 21 / 98}{\text { Date }}$}

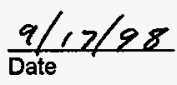




\section{TABLE OF CONTENTS}

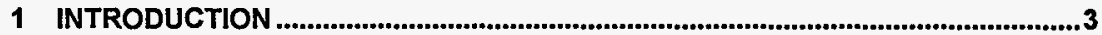

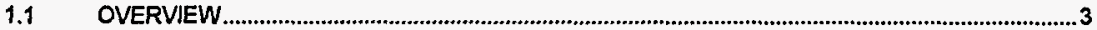

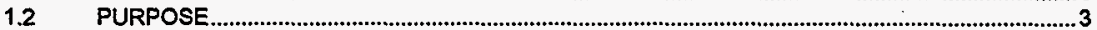

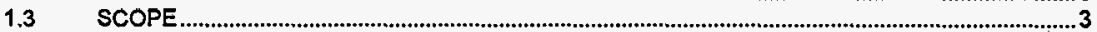

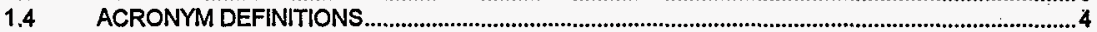

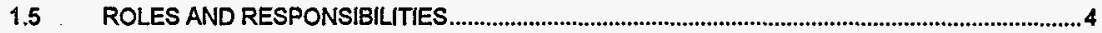

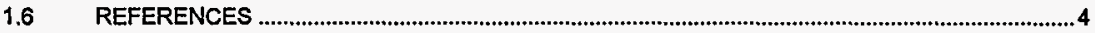

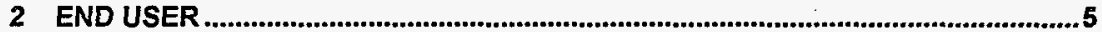

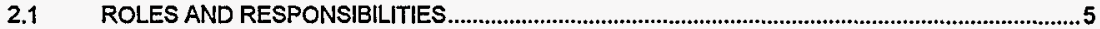

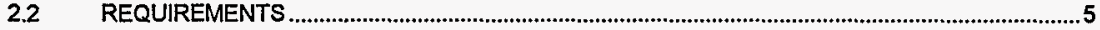

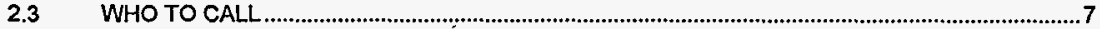

3 BMS PATROL ..............................................................................................................8

3.1 PURPOSE OF BMS PATROL

3.2 BMS PATROL ROLES AND RESPONSIBILITIES................................................................................

3.3 METHOD TO IDENTIFY BMS PATROL POCS ……..........................................................................8

3.4 PATROL GUIDANCE

4 CUSTOMER TECHNICAL SUPPORT ….............................................................9

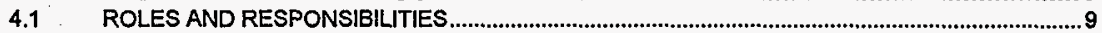

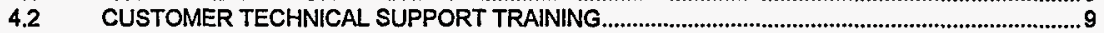

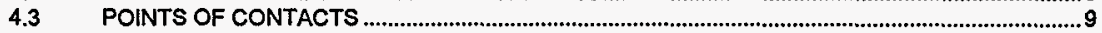

4.4 HANFORD USER HELP INFORMATION .............................................................................................

5 TRAINING ............................................................................................................10

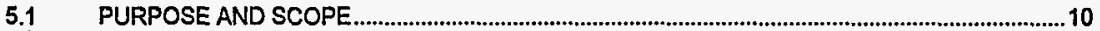

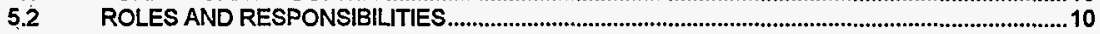

6 IMPLEMENTATION TEAM ...................................................................................11

6.1 PURPOSEAND SCOPE...............................................................................................................11

6.2 RESPONSIBILITIES ..........................................................................................................11

COMMUNICATION METHODS......................................................................................12

7.1 IMPLEMENTATION TEAMS ......................................................................................12

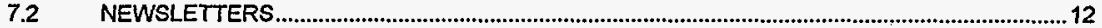

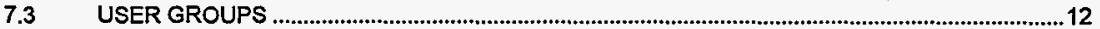

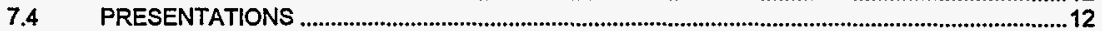

7.5 END USER FEEDBACK MECHANISMS

8 APPENDIX A IMPLEMENTATION TEAM POINTS OF CONTACT ........................13

9 APPENDIX B TRAINING COURSES .................................................................15

10 APPENDIX C END USER HELP PROCESS FLOW ...........................................19

11 APPENDIX D HANDI 2000 PATROL POINTS OF CONTACT ...........................21

12 APPENDIX E REQUIRED ACCESS TRAINING .................................................22 


\section{INTRODUCTION}

\subsection{OVERVIEW}

The Hanford Data Integration 2000 (HANDI 2000) Project will result in an integrated and comprehensive set of functional applications containing core information necessary to support the Project Hanford Management Contract (PHMC). It is based on the Commercial-Off-The-Shelf (COTS) product solution with commercially proven business processes. The COTS product solution set, of PassPort (PP) and PeopleSoft (PS) software, supports finance, supply, human resources, and payroll activities under the current PHMC direction. The PP software is an integrated application for Accounts Payable, Contract Management, Inventory Management, Purchasing and MSDS. The PS software is an integrated application for Projects, General Ledger, Human Resources/Training, Payroll, and Base Benefits. This set of software constitutes the Business Management System (BMS), a subset of the HANDI 2000 suite of systems.

\subsection{PURPOSE}

The primary objective of the End User Support Plan (EUSP) is to ensure that the end users have access that is reasonable and commensurate with job position functionality in order to perform their work effectively. Another objective is to ensure user support is provided to utilize the new BMS while minimizing significant security risks to BMS. The EUSP becomes effective as of this document's acceptance and will provide guidance through implementation efforts and, as a "living document", will support the operations and maintenance of HANDI 2000 systems.

\subsection{SCOPE}

This document encompasses and standardizes the integrated approach for end user support for the BMS. It also identifies the support methods to be used. The scope of security applies to the BMS applications. The BMS is comprised of the following vendor product modules as databases:

\begin{tabular}{|l|l|l|}
\hline \multicolumn{1}{|c|}{$\begin{array}{c}\text { Business Management } \\
\text { System }\end{array}$} & \multicolumn{1}{|c|}{ Vendor Product } & \multicolumn{1}{|c|}{ Vendor Modules } \\
\hline Finance Management & PeopleSoft & $\begin{array}{l}\text { General Ledger } \\
\text { Projects Module }\end{array}$ \\
\hline Supply Management & PassPort & $\begin{array}{l}\text { Accounts Payable } \\
\text { Inventory Management } \\
\text { Contracts Management } \\
\text { Purchasing }\end{array}$ \\
\hline Chemical Management & PassPort & MSDS \\
\hline Human Resources & PeopleSoft & $\begin{array}{l}\text { Human Resources } \\
\text { Training }\end{array}$ \\
\hline Payroll & PeopleSoft & $\begin{array}{l}\text { Payroll } \\
\text { Base Benefits }\end{array}$ \\
\hline
\end{tabular}




\subsection{ACRONYM DEFINITIONS}

\begin{tabular}{|l|l|}
\hline \multicolumn{1}{|c|}{ Acronym } & \multicolumn{1}{c|}{ Definition } \\
\hline BMS & Business Management System \\
\hline CTS & Customer Technical Support \\
\hline EUSP & End User Support Plan \\
\hline FDH & Fluor Daniel Hanford, Incorporated \\
\hline H2K & HANDI 2000 \\
\hline HANDI 2000 & Hanford Data Integration Project \\
\hline HLAN & Hanford Local Area Network \\
\hline HR/PR & Human Resources/Payroll \\
\hline HUH & Hanford User Help \\
\hline LMSI & Lockheed Martin Services, Incorporated \\
\hline PHMC & Project Hanford Management Contract \\
\hline POC & Point of Contact \\
\hline PP & Indus PassPort software \\
\hline PS & PeopleSoft software \\
\hline
\end{tabular}

\subsection{ROLES AND RESPONSIBILITIES}

Roles and responsibilities for end user support will be defined in the following areas:

- End Users

- BMS Patrol

- Customer Technical Support (CTS)

- Training

- Implementation Team

\subsection{REFERENCES}

HNF-3206 Appendix A Appendix B Appendix $C$ Appendix D
HANDI 2000 Training Plan Implementation Team Points of Contact Training Courses

End User Help Process Flow HANDI 2000 Patrol Points of Contact 


\section{END USER}

\subsection{ROLES AND RESPONSIBILITIES}

End users are the application users of the BMS systems. They are responsible for reporting any problems they incur with the BMS applications.

\subsection{HARDWARE AND SOFTWARE REQUIREMENTS}

\subsubsection{Minimum Work Station Requirements}

Reference the following table for user roles and minimum hardware and sofware workstation requirements

\begin{tabular}{|c|c|c|}
\hline User type & Definition & Minimum Workstation Requirements \\
\hline Power User & $\begin{array}{l}\text { Personnel utilizing PP or PS applications } \\
\text { to accomplish their daily work }\end{array}$ & $\begin{array}{l}\text { PP Client Workstation } \\
\text { Pentium } 100 \text { Processor } \\
32 \text { MB RAM } \\
60 \text { MB Available Disk Space } \\
\text { Windows } 95 \\
\text { Portal/97 PassPort Interface } 6.0 .1 \\
\text { PS Financials Client Workstation } \\
\text { PeopleSoft } 7.0 \\
\text { SQL"Net for users running Crystal Reports } \\
\text { PS HR/PR Client Workstation } \\
\text { PeopleSoft } 7.0 \\
\text { PeopleTools } 7.01 \\
\text { Windows } 95 \text { or NT } 4.0 \\
\text { SQL Server Driver } 2.65 .0240 \text { or later } \\
\text { ODBC -32 bit } \\
\text { SQL"Net for users running Crystal Reports }\end{array}$ \\
\hline Periodic User & $\begin{array}{l}\text { Personnel who may require PP or PS } \\
\text { applications to do some of their work but } \\
\text { not necessarily on a daily basis. }\end{array}$ & $\begin{array}{l}\text { PP Client Workstation } \\
\text { Pentium } 100 \text { Processor } \\
32 \text { MB RAM } \\
60 \text { MB Available Disk Space } \\
\text { Windows } 95 \\
\text { Portal/97 PassPort Interface } 6.0 .1 \text { or } \\
\text { Portal G PassPort Interface } 6.0 .1 \\
\\
\text { PS Financials Client Workstation } \\
\text { PeopleSoft } 7.0 \\
\text { SQL*Net for users running Crystal Reports } \\
\text { PS HR/PR Client Workstation } \\
\text { PeopleSoft } 7.0 \\
\text { PeopleTools } 7.01 \\
\text { Windows } 95 \text { or NT } 4.0 \\
\text { SQL Server Driver } 2.65 .0240 \text { or later } \\
\text { ODBC - 32 bit } \\
\text { SQL*Net for users running Crystal Reports }\end{array}$ \\
\hline
\end{tabular}




\begin{tabular}{|c|c|c|}
\hline Casua/ User & $\begin{array}{l}\text { Personnel who may require PP or PS } \\
\text { application on an occasional basis. }\end{array}$ & $\begin{array}{l}\text { PP Client Workstation } \\
486 / 33 \text { MHz Processor } \\
16 \text { MB RAM } \\
60 \text { MB Available Disk Space } \\
\text { Windows } 95 \\
\text { Portal/97 PassPort Interface } 6.0 .1 \text { or } \\
\text { Portal G PassPort Interface } 6.0 .1 \\
\\
\text { PS Financials Client Workstation } \\
\text { Pentium } 100 \text { Processor } \\
32 \text { MB RAM } \\
60 \text { MB Available Disk Space } \\
\text { Windows } 95 \\
\text { PeopleSoft } 7.0 \\
\text { SQL"Net for users running Crystal Reports } \\
\text { PS HR/PR Client Workstation } \\
\text { Pentium } 100 \text { Processor } \\
32 \text { MB RAM } \\
100 \text { MB Available Disk Space } \\
\text { PeopleSoft } 7.0 \\
\text { PeopleTools } 7.01 \\
\text { Windows } 95 \text { or NT } 4.0 \\
\text { SQL Server Driver } 2.65 .0240 \text { or later } \\
\text { ODBC - } 32 \text { bit } \\
\text { SQL*Net for users running Crystal Reports }\end{array}$ \\
\hline
\end{tabular}

The recommendation is that all users of the HANDI 2000 software have a Pentium 100 processor or better. The faster machines will help significantly in the acceptance of new business processes.

As organizations procure new workstations they should refer to the site standards for new purchases.

\subsubsection{Software}

In addition to the above software on client workstations, End users must have Hanford Local Area Network (HLAN) access installed. Sofware Distribution Winlnstall Hanford Site Applications will be used to download the appropriate software for PassPort and PeopleSoft to the client workstation.

\subsubsection{Training}

End users will be trained according to their user level and business need prior to being given access to any of the BMS application production regions. This will be through formal classes and informal training through the Patrol POC's or other power users. For additional information on mandatory training, reference Appendix E, Required Access Training. 


\subsection{WHO TO CALL}

- Business questions - Patrol POC

- Computer application system questions - Patrol POC

- General logging on and printing questions - Customer Technical Support (CTS)

For additional information, reference Appendix C, End User Help Process Flow. 


\section{HANDI 2000 PATROL}

The HANDI 2000 Patrol is comprised of individuals who are experts in the affected business areas. Patrol participants fulfill a crucial role in the successful implementation of the BMS. The Patrol provides hands-on help to users within their own projects and facilities. New users will have someone to go to with whom they are familiar and that will be available to them. This will lessen some of the stress associated with using a "new" system. The Patrol's primary function is to service users of the new system - it is not to police the usage of the new BMS system.

\subsection{PURPOSE OF HANDI 2000 PATROL}

The purpose of the HANDI 2000 Patrol is to promote the successful implementation of the new BMS system and will continue to provide support in the production environment. Users will be instructed to first contact their Patrol POC with business and system questions. The Patrol participants will provide hands-on support to users of the new system. End user support will supplement to user training.

\subsection{HANDI 2000 PATROL ROLES AND RESPONSIBILITIES}

Patrol POCs are experts in their appointed business process area and understand the "old" and "new" ways of doing business. They are also expert users of the system application supporting the business process areas. It is important that Patrol POCs have time to provide end user support and that their support is fully endorsed by management. Patrol POCs are responsible for the following:

- Must be available to support users - especially during initial implementation periods

- Must be available for user phone calls

- Provide workstation support locally (at user workstations)

- May provide overview sessions, as appropriate.

\subsection{METHOD TO IDENTIFY HANDI 2000 PATROL POCs}

FDH has formed an Implementation Team comprised of representatives from each of the major PHMC contractors and projects. The representatives are responsible for providing the Integration Coordinator with the names of the Patrol candidates for their project/facilities for each primary business area they deem necessary, (i.e., buyers, contract, material requisitioning for Supply, $P 3$ and reporting for Finance, and Chemical Management). For additional information regarding Implementation Team members, reference Appendix A, Implementation Team Points of Contact and Appendix D, HANDI 2000 Patrol Points of Contact.

\subsection{PATROL GUIDANCE}

Patrol POCs will be attending all applicable courses prior to other users, It is recommended that Patrol POCs participate in system testing, taking place from July through September 1998, enabling efficient and focused familiarization with the computer systems. Reference HNF-3206 HANDI 2000Training Plan for additional information. 


\section{CUSTOMER TECHNICAL SUPPORT}

\subsection{ROLES AND RESPONSIBILITIES}

CTS will be fielding user calls. CTS will be handling general user questions and will be provided a list of contacts for each of the BMS applications.

\subsection{CUSTOMER TECHNICAL SUPPORT TRAINING}

An overview training session will be held for CTS personnel. CTS will determine whether or not they will send any individuals to the application specific training.

\subsection{POINTS OF CONTACTS}

A list of BMS Points of Contact (POC) names will be provided to CTS. The lists will be comprised of the following information:

- Primary Business POC

- Patrol POC

- Technical POC

\subsection{HANFORD USER HELP INFORMATION}

Hanford User Help (HUH) information is being collected for the three software products, PassPort, PeopleSoft, and Primavera Project Planner. Each software product has a folder in the HUH directory. Project support personnel have been notified of the location of these files and were asked to provide information in question and answer format to capture this help information. This information will be used to support CTS, patrol team members, project support personnel, and end users.

http:/wnw.rl.gov:1050/huh/findex.hitm 


\section{TRAINING}

\subsection{PURPOSE AND SCOPE}

Overview training courses are planned for August 1998. Application level courses will be offered in August and September of 1998. Patrol POCs and power users will be scheduled into these classes prior to other users because they play a key implementation roll. They will be providing support to other end users. Upon completion of the overview courses, users will be granted access to a "Practice" region to allow them to become familiar with the systems. For additional training information, reference Appendix B Training Courses.

\subsection{ROLES AND RESPONSIBILITIES}

FDH is responsible for the following:

- Providing training

- Maintaining and updating the training courseware

- Coordinating training schedules

- Preparing training material

- Providing training facilities 


\section{IMPLEMENTATION TEAM}

\subsection{PURPOSE AND SCOPE}

FDH formed an Implementation Team to serve as the field coordinator for HANDI 2000 rollout. Representatives from each of the major projects will ensure their respective project or function is ready for implementation on October 1, 1998. The Implementation Team will work closely with Project Direction POCs. The Team will evaluate impacts of the new workflow processes and take action to minimize impacts. Each team member will be responsible for assessing their project for impacts and determining training, computer hardware, procedural changes, and communication needs.

The Implementation Team consists of a representative from the following major projects: Spent Nuclear Fuel, Tank Waste Remediation Services, Waste Management, and Facility Stabilization. An Implementation team member is also assigned for the following support functions: Infrastructure and Numatec. Reference Appendix A, Implementation Team Points of Contact.

\subsection{RESPONSIBILITIES}

The Implementation Team will be responsible for:

- Managing field implementation schedules

- Communicating

- Process flows

- Process user roles

- Equipment requirements and needs

- Identifying training requirements and needs

- Any other communication needs as they arise

- Developing recovery strategies for business process changes (including terminology differences and definitions)

- Identifying and communicating affected project/field procedures

- Coordinating the review and changes of affected project/field procedures

- Ensuring primary data loading requirements are satisfied

- Identifying affected personnel

- Ensuring affected personnel

- Have been provided training opportunity

- Have adequate desktop tools

It is recommended that team members utilize process owners from the field and BPI participants as resources. For additional information, reference Appendix A, Implementation Team Points of Contact. 


\section{COMMUNICATION METHODS}

Communication to the End Users is accomplished in a variety of ways including, but not limited to

- General Employee Overviews (Road Show)

- All-employee emails and bulletins

- Newsletters

- Workshops

\subsection{IMPLEMENTATION TEAMS}

FDH has formed an Implementation Team to serve as the field coordinator for HANDI 2000 rollout. Each major project has a POC on the Implementation Team. One responsibility of team members is communication. This is comprised of communicating to the field, the forthcoming changes to affected business areas within their projects. In addition, the team communicates the field needs and impacts to FDH and the BMS business process owner representatives.

\subsection{NEWSLETTERS}

FDH is publishing a newsletter for the HANDI 2000 BMS project from "HANDI Mandy". The Finance subproject of HANDI 2000 is also publishing newsletters Reference the H2K home page to have names added to the mailing lists and for additional H2K information. Articles are published in the "Hanford REACH"

\subsection{USER GROUPS}

It is recommended that user groups are formed and remain active throughout the lifecycle of the BMS.

\subsection{PRESENTATIONS}

The project teams are performing "road shows" to interested stakehoiders, including process owners, users and managers. Presentations will continue after implementation.

\subsection{END USER FEEDBACK MECHANISMS}

Prior to production, End Users are encouraged to provide feedback to the business process owners and their Implementation Team POCs. Upon and after production, End Users are encouraged to continue providing feedback to the business process owners and BMS Patrol POCs, and to participate in user groups. 


\section{APPENDIX A IMPLEMENTATION TEAM POINTS OF CONTACT}

August 12, 1998

\section{Project Implementation Leads}

$\begin{array}{llr}\text { Dana Worthington } & \text { Spent Nuclear Fuels (DESH) } & 376-9831 \\ \text { Jeff Rampon } & \text { Spent Nuclear Fuels (DESH) } & 376-0289 \\ \text { Linda Powers } & \text { Waste Management (WMH) } & 372-3975 \\ \text { Alan Grasher } & \text { Facility Stabilization (BWHC) } & 373-2565 \\ \text { Mike Wells } & \text { Tank Waste Remediation System (LMHC) } & 373-2078 \\ \text { Miriam Steffen } & \text { NHC } & 376-3168 \\ \text { Bruce Lenzer } & \text { infrastructure (DynCorp) } & 373-3584 \\ \text { Roger Corless } & \text { FDH } & 372-8219 \\ \text { Pat Marmo } & \text { FDH } & 376-1383\end{array}$

HANDI 2000 Contacts

Wendy Scott

John Bickford

Ed Gibson

Scott Bennion

Dawn Adams

Bill Bowen

Bob Aaron

Tim Stokes

Chris Hopkins

Paul Felts

Chris Wiprud

Pam Edwards

Mike Stephenson

Jim Fish

Gary Duncan

Terri Lutter

Chris Maiden-Lowe
HANDI 2000 (FDH)

$373-2463$

HANDI 2000 (FDH)

373-7664

HANDI 2000 (FDH)

376-6567

HANDI 2000 (FDH)

$376-6755$

HANDI 2000 (FDH)

376-1005

Reengineering (FDH)

372-0182

HANDI 2000 Training (FDH)

HANDI 2000 Training (FDH)

373-3302

HANDI 2000 Supply (FDH)

376-3275

HANDI 2000 Finance (FDH)

376-0367

HANDI 2000 Finance (FDH)

376-0478

HANDI 2000 Human Resources (FDH)

$376-7175$

HANDI 2000 Chemical Management (FDH)

376-3870

HANDI 2000 Project Management (FDH)

376-0778

HANDI 2000 Work Management (FDH)

376-6008

LMSI Integration

376-2991

LMSI Integration 
HANDI 2000

DOC ITEM: End User Support Plan

HNF 2712, Rev.0

DATE: 09/15/98

Linda Blumer

LMSI Integration/Data Management

$376-2836$

Pat Baynes

Site Systems Engineering (LMHC)

$372-3583$

Sandy Evosevich

LMSI

$376-7451$

Brian Isaacs

LMSI

$376-8776$

Cynthia Hightower

DESH Training

372-0085

Karolyn Friday

$\mathrm{FDH} / \mathrm{ClO}$

$376-4077$

\section{Labor Relations}

Gerald Saskowsky Labor Relations (FDH)

$373-1813$

Keith Smith, Jr.

HAMTC

$376-6965$

\section{Project Direction POCs}

Dave Eder

Jerry Bosley

Jeff Rampon

Marcella Baumann

Phil Townsend

Mike Skriba

Andy Wirkkala

Paul Mendez
WM POC (Project Direction)

TWRS POC (Project Direction)

SNF POC (Project Direction)

Facilities Stabilization POC (Project Direction)

Infrastructure POC (Project Direction)

Numatec POC (Project Direction)

DOE POCs

DOE Asst. Mgr. For Facility Transition

DOE Financial Management Division
376-0755

373-5177

376-0289

372-3672

373-3718

376-8192

373-7835

376-6645 


\section{APPENDIX B TRAINING COURSES}

\section{COURSE MATRIX \\ Inventory Management}

Training Breakdown By Functional Group

\begin{tabular}{|c|c|c|c|c|}
\hline FUNCTIONAL USER GROUP & 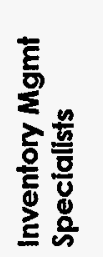 & 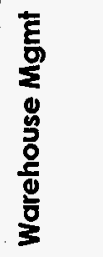 & 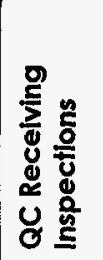 & 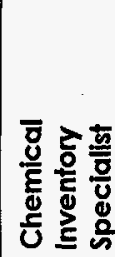 \\
\hline Inventory Management & $\begin{array}{l}\text { INV-001 } \\
085040\end{array}$ & $\begin{array}{l}\text { INV-002 } \\
085045\end{array}$ & $\begin{array}{l}\text { INV-003 } \\
085050\end{array}$ & \begin{tabular}{|l|} 
INV-004 \\
085055
\end{tabular} \\
\hline System Basics Review & $\bar{x}$ & $\bar{x}$ & $\bar{x}$ & $\bar{x}$ \\
\hline System Administration Set-Up & $x$ & & & $x$ \\
\hline Standards \& Procedures & $\mathbf{x}$ & & & $\mathbf{x}$ \\
\hline Master Catalog - View-Only & & $\bar{x}$ & $\bar{x}$ & \\
\hline Master Catalog - Create/Update & $\bar{x}$ & & & $\bar{x}$ \\
\hline Warehouse Location Data & $x$ & $\bar{x}$ & & $x$ \\
\hline Material Reservation-D208 & $\bar{x}$ & & & \\
\hline Vendor Data - View-Only & $\bar{x}$ & $\bar{x}$ & $\bar{x}$ & $\bar{x}$ \\
\hline \multicolumn{5}{|l|}{ Vendor Data - Create/Update } \\
\hline Material Request & $\bar{x}$ & $\underline{x}$ & $\bar{x}$ & $\bar{x}$ \\
\hline New Item Initiation - 0209 & $\bar{x}$ & & $\bar{x}$ & $\bar{x}$ \\
\hline Electronic Reorder Notice & $x$ & & & \\
\hline Purchase Requisitions & $\underline{x}$ & & $\bar{X}$ & $\bar{x}$ \\
\hline Receiving & $\bar{x}$ & $\mathbf{x}$ & $\bar{x}$ & $\bar{x}$ \\
\hline Over, Short, Damaged \& Discrepant (OSD\&D) & $\overline{\mathbf{x}}$ & $\bar{x}$ & $\bar{x}$ & $\bar{x}$ \\
\hline $\begin{array}{l}\text { QC Inspection/UTC } \\
\text { Uniquely-Tracked Commodities }\end{array}$ & $\bar{x}$ & $\mathbf{x}$ & $\mathbf{x}$ & $\bar{x}$ \\
\hline Warehouse Distribution & $\mathbf{x}$ & $\mathbf{x}$ & & $x$ \\
\hline Stock Putaway - Quick Putaway & $\mathbf{x}$ & $\bar{x}$ & & $\bar{x}$ \\
\hline $\begin{array}{l}\text { Pick Backlog - Pick Backlog Scheduling } \\
\text { \& Pick Upload }\end{array}$ & $\bar{x}$ & $\bar{x}$ & & \\
\hline On-Demand Pick Request & $\bar{x}$ & $\bar{x}$ & & $\bar{x}$ \\
\hline Pick Consolidation \& Issue & $\bar{x}$ & $\bar{x}$ & & $\bar{x}$ \\
\hline Parts/Tool lssue \& Return & $x$ & $\underline{x}$ & $\bar{x}$ & $\bar{x}$ \\
\hline Material Movement Within Warehouse & $\bar{x}$ & $\bar{x}$ & & $\bar{x}$ \\
\hline Returns to Vendors & $\bar{x}$ & $\underline{\mathbf{x}}$ & $\mathbf{x}$ & $x$ \\
\hline Replenishments Min/Max Reorder Points & $\bar{x}$ & & & \\
\hline Cycle Counting & $\mathbf{x}$ & $\mathbf{x}$ & & $\bar{x}$ \\
\hline Forecasting & $x$ & & & \\
\hline Reporting \& Analysis Tools & $\bar{x}$ & $\bar{x}$ & $\mathbf{x}$ & $\bar{x}$ \\
\hline
\end{tabular}


Training Group Breakdown By Functional Group

\begin{tabular}{|c|c|c|c|c|c|c|c|c|}
\hline FUNCTIONAL USER GROUP: & 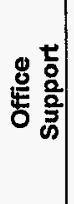 & 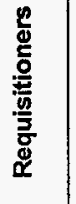 & 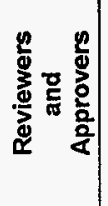 & 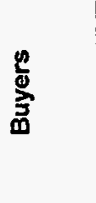 & 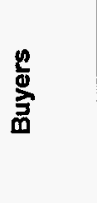 & 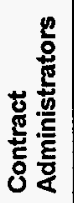 & 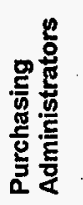 & 旁兽 \\
\hline COURSE IDENTIFICATION & 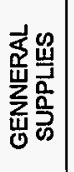 & 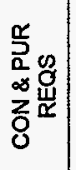 & 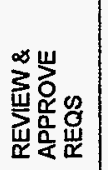 & 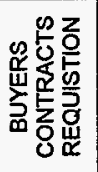 & 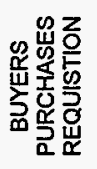 & 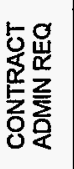 & 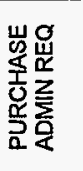 & 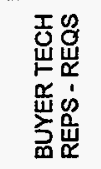 \\
\hline $\begin{array}{r}\text { Previous Course ID } \\
\text { And } \\
\text { Approved Course ID }\end{array}$ & $\begin{array}{l}5 \\
\delta \\
\end{array}$ & 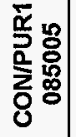 & 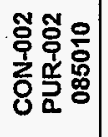 & 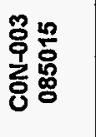 & 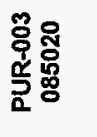 & 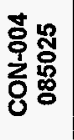 & 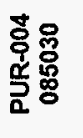 & 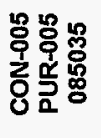 \\
\hline Introduction & $\mathbf{x}$ & $x$ & $x$ & $\mathbf{x}$ & $\mathbf{x}$ & $\mathbf{X}$ & $\mathbf{X}$ & $\mathbf{X}$ \\
\hline Setting Up Contract Data & & & & $\mathbf{x}$ & & $\mathbf{x}$ & & $\mathbf{x}$ \\
\hline Contract Requisitions & & $\mathbf{X}$ & $\mathbf{x}$ & $\mathbf{x}$ & & $\mathbf{x}$ & & $\mathbf{x}$ \\
\hline Requisition Backlog & & & $\mathbf{x}$ & & & $\bar{x}$ & & \\
\hline Request for Proposal & & & & & & $x$ & & \\
\hline Contract Processing & & & $X$ & & & $\mathbf{X}$ & & \\
\hline Contract Amendments & & & & & & $\mathbf{x}$ & & \\
\hline Payment Authorization & & & & & & $\mathbf{X}$ & & $\mathrm{X}$ \\
\hline Request For Vendor Evaluation & & $\mathbf{X}$ & $\mathbf{X}$ & & $x$ & & $\mathbf{x}$ & \\
\hline Material Requests & $\mathbf{x}$ & $\mathbf{x}$ & & & $\bar{x}$ & & $\underline{x}$ & \\
\hline Open Requisition Backlog & & & $\mathrm{X}$ & & $\mathrm{x}$ & & & \\
\hline Purchase Award Processing & & & ** & & $X$ & & & \\
\hline Purchase Orders & & & ** & & $x$ & & & \\
\hline Blanket Purchase Orders & & & & & $\mathbf{x}$ & & & \\
\hline Auto Award Purchasing & & & & & $\mathbf{x}$ & & & \\
\hline Expediting Purchase Orders & & & & & $x$ & & & \\
\hline PO Revisions and Cancellations & & $\mathbf{x}$ & $\mathbf{x}$ & & $\bar{x}$ & & & \\
\hline Réquest for Quotation & & & & & $\bar{x}$ & & & \\
\hline Recording Vendor Bid Responses & & & & & $\mathbf{x}$ & & & \\
\hline Management Reporting & & $\mathbf{X}$ & $\mathbf{x}$ & & $\mathbf{x}$ & $\mathbf{x}$ & & $\bar{x}$ \\
\hline - Managing AAA's & $\mathbf{x}$ & $x$ & $\mathbf{x}$ & $\mathbf{x}$ & $\mathbf{X}$ & $\mathbf{x}$ & $\mathbf{X}$ & $x$ \\
\hline
\end{tabular}

- Indicates that this material is not part of the standard INDUS Training Courseware but is a requirement.

* Indicates - OVERVIEW

An ' $X$ ' in the column defines the required training for the specified job function. 


\section{FINANCE COURSES}

\section{Course Number: FIN-001}

Fiscal Year Startup Workshop, Rev. 1

\section{Purpose Statement}

To provide the detailed information project control/financial staff and management need for fiscal year end/start-up.

\section{Description}

This session will instruct all project control/financial management and staff on how to apply the new set of business practices, to fiscal yearend/startup. Topics covered will cross organizational boundaries such as Finance, Planning, Acquisitions, and Contracts. As an example, see last year's topics listed below. This year's should be similar, but take into account new system impacts.

- Planning/Budgeting for Home Office Support

- Setting up Purchase Orders/Task Orders

- Month-end Reporting/Processing Schedule

- FDH Reporting Requirements

- Facility

\section{Codes/Crosscharging}

- Direct Funded Activities

- Rate

Changes/Structure

- Planning/Budgeting for Enterprise Company Work

- Request for Service (RFS) Process

- Capital Accounting
- Accrual Process

- New RL WBS

- HANDI

- P3 Conversion

- Reference Materials

- Question \& Answer

\section{Audience}

Project control/financial management and staff who are involved with the control, monitoring, and reporting of budget, performance, and cost of projects.

\section{Classroom Resources and Planning}

Time: $\sim 3$ Hrs

Methods: Lecture and discussion

NOTE: It is anticipated that at least four of these workshops will be held, both in the outer areas and downtown. 


\section{Course Number: FIN-002 \\ Project Reporting and Information Sources, Rev. 1}

\section{Purpose Statement}

To inform and instruct project control/financial management and staff on utilizing the HANDI 2000 PERF and Soft Reporting(or SR replacement) reporting tools at their disposal.

\section{Description}

This course will provide reference materials on business practice, coding structure, and terminology changes, but will focus on the reporting tools available beginning 10/1/98. It will cover the reporting capabilities available, what kind of information is housed where, how to access the information and navigate in the various reporting tools. The course will also provide points of contact and other resources for additional information. NOTE: Recognizing the overall reporting infrastructure is still being worked, it is anticipated "reporting tools" may include, but not be limited to, HANDI, PERF and Soft Reporting replacement.

\section{Classroom Resources and Planning}

Time: $\sim 4 \mathrm{Hrs}$

Methods: Lecture, discussion, and computer demonstration,

Pre-Requisite: This course will be a pre-requisite for Course No. FIN-003, Advanced Project Control Data Sources.

NOTE: This course replaces \# 005005, FDS Overview \& Soft Reporting. Lab time will also be provided.

\section{Course Number: FIN-003 \\ Advanced Project Data Control Sources, Rev. 1}

\section{Purpose Statement}

To inform and instruct project control/financial management and staff on interpretation of report data and research of detailed transaction records.

\section{Description}

This course should increase the understanding of how a transaction flows through the new system(s) so that staff can find the information they need to control, monitor, and report the budget, performance, and cost of projects. Using case scenarios, participants should learn to:

- Locate or generate specific reports/information

- Exporting data to products such as Excel.

- Interpret report data to identify potential problem areas

- Research problem areas to their source for purposes such as variance reporting, correction, change control, etc.

- The process to resolve questionable data or charges.

The course will also provide points of contact and other resources for additional information, including reference to guiding procedures.

\section{Audience}

Project control/financial staff whose primary job function is the control, monitoring, and reporting of budget, performance, and cost of projects.

\section{Classroom Resources and Planning}

Time: $\sim 4 \mathrm{Hrs}$

Methods: Lecture, discussion, and hands-on computer practices.

Pre-Requisite: Course No. FIN-002, Project Control Data Sources. 


\section{APPENDIX C END USER SUPPORT PROCESS FLOW}

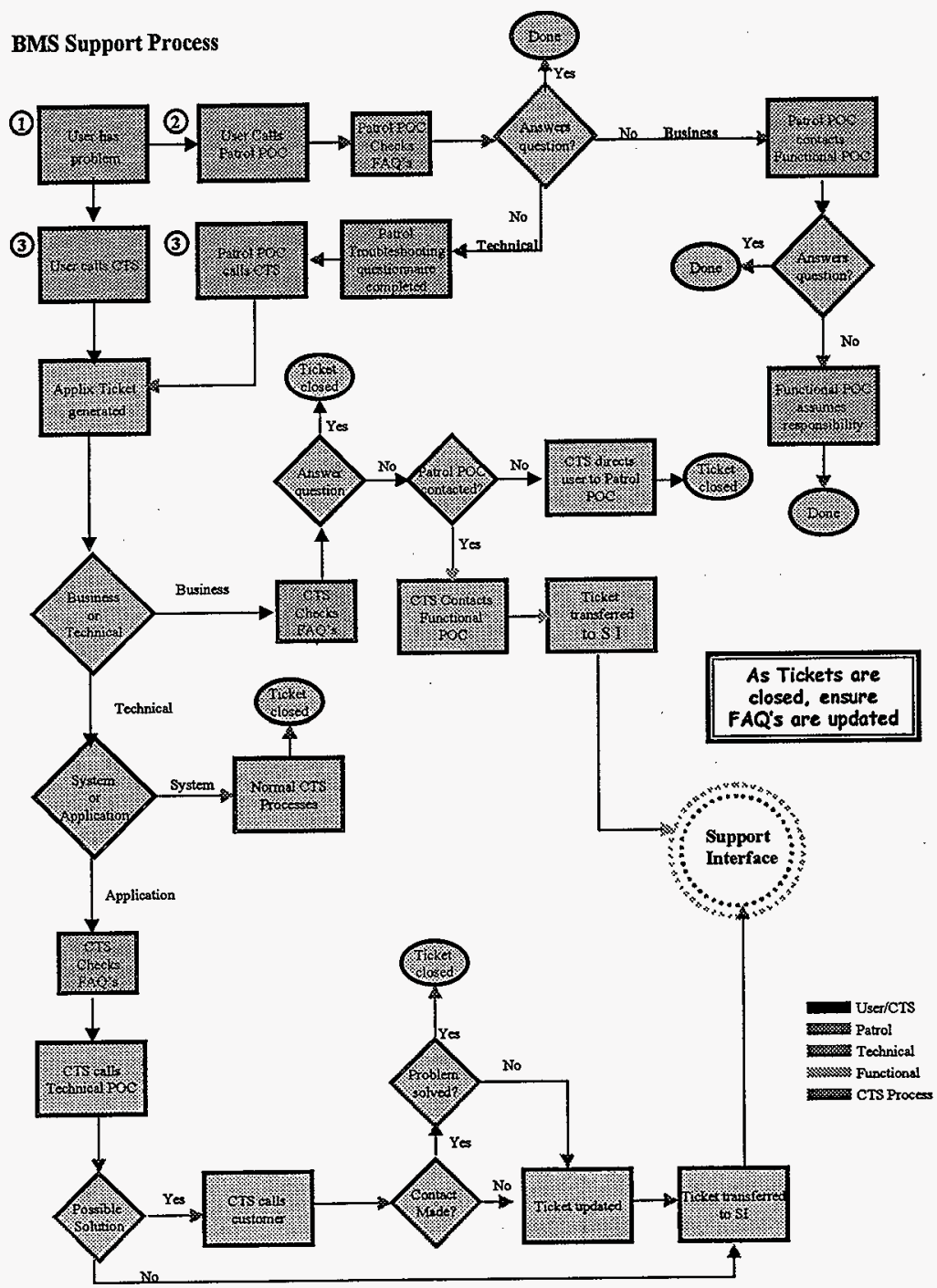


HNF-2712, Rev. 0

Page 20 of 23

This page intentionally blank. 
HANDI 2000

DOC ITEM: DRAFT End User Support Plan

HNF 2712, Rev.0

DATE: $7 / 17 / 98$

PAGE: 21 of 23

\section{APPENDIX D HANDI 2000 BMS PATROL POINTS OF CONTACT}

\begin{tabular}{|c|c|c|c|c|c|c|c|}
\hline $\begin{array}{c}\text { Company } \\
\text { Project }\end{array}$ & Supply-Buyers & $\begin{array}{l}\text { Supply- } \\
\text { Contracts }\end{array}$ & $\begin{array}{c}\text { Supply-Material } \\
\text { Requests I } \\
\text { Catalog }\end{array}$ & Finance-P3 & Finance-Reports & $\begin{array}{l}\text { Chemical } \\
\text { Management }\end{array}$ & $\begin{array}{c}\text { Human } \\
\text { Resources }\end{array}$ \\
\hline FDH & $\begin{array}{l}\text { Mike D. Taylor } \\
\text { Bob Moore }\end{array}$ & Lois Hill & $\begin{array}{l}\text { Chris Hopkins } \\
\text { KIm Schultz } \\
\text { Brent Wagner }\end{array}$ & $\begin{array}{l}\text { Larry Andros } \\
\text { Margaret Davis } \\
\text { Don Layfiefld } \\
\text { Chris Wiprud } \\
\text { Kevin Mclntosh } \\
\text { Joe Tarcza }\end{array}$ & $\begin{array}{l}\text { Larry Andros } \\
\text { Margaret Davis } \\
\text { Don Layfiefld } \\
\text { Chris Wiprud } \\
\text { Kevin Mcintosh }\end{array}$ & Mike Stephenson & $\begin{array}{l}\text { Pam Edwards } \\
\text { Didi Staudacher } \\
\text { Connie Ratliff }\end{array}$ \\
\hline $\begin{array}{l}\text { BWHCI I } \\
\text { Facility } \\
\text { Stabilization } \\
\text { and Advanced } \\
\text { Reactors }\end{array}$ & Anne Thompson & Anne Thompson & Gerald Maiuri & Liesa Kinsey & $\begin{array}{l}\text { Paul Bodmer } \\
\text { Kay Barron } \\
\text { Janie Salazar }\end{array}$ & Dennis Tumer & Joan Eckert \\
\hline $\begin{array}{l}\text { DESH I } \\
\text { Spent Nuclear } \\
\text { Fuels }\end{array}$ & Dana Worthington & Bob Willard & BobWillard & Clyde Gilson & Clyde Gilson & $\begin{array}{l}\text { Phil Colgan } \\
\text { Chuck Detrick }\end{array}$ & N/A \\
\hline $\begin{array}{l}\text { DYN/ } \\
\text { Infrastructure }\end{array}$ & $\begin{array}{l}\text { Rob Sheehy } \\
\text { Stan Cottrell } \\
.\end{array}$ & Stan Cottrell & $\begin{array}{l}\text { TBD (2101M) } \\
\text { TBD (400/4732A) } \\
\text { Paulette White(1163) } \\
\text { Erma Vaughn(1163) }\end{array}$ & $\begin{array}{l}\text { JoAnn Crigler } \\
\text { Sheri Stolle }\end{array}$ & Cliff Stice & $\begin{array}{l}\text { Robyn Currier } \\
\text { Brian Dixon }\end{array}$ & Josie Villa \\
\hline $\begin{array}{l}\text { LMHCI } \\
\text { Tank Waste } \\
\text { Remediation } \\
\text { System }\end{array}$ & $\begin{array}{l}\text { Renee Finke } \\
\text { Alice Hendrickson } \\
\text { Laurie Cortez }\end{array}$ & $\begin{array}{l}\text { Ralph Wood } \\
\text { Laurle Cortez }\end{array}$ & $\begin{array}{l}\text { Renee Finke } \\
\text { Laurie Cortez }\end{array}$ & \begin{tabular}{|l|} 
Mike Lewis \\
Jim Blethan
\end{tabular} & $\begin{array}{l}\text { Al Gotschalk } \\
\text { Heather Schut } \\
\text { Linnea Williams }\end{array}$ & $\begin{array}{l}\text { Steve Staley } \\
\text { Troy Hanford } \\
\text { John Hasson }\end{array}$ & Carrie Locke \\
\hline$\overline{\mathrm{NHC}}$ & $\begin{array}{l}\text { Miriam Steffan } \\
\text { TBD }\end{array}$ & TBD & Linda Gibson & $\begin{array}{l}\text { Roy Brogdon } \\
\text { Dwight Carter }\end{array}$ & Pam Fitzgibbons & N/A & $\mathrm{N} / \mathrm{A}$ \\
\hline $\begin{array}{l}\text { WMH I } \\
\text { Waste } \\
\text { Management }\end{array}$ & Tracey Burch & Kelli Gier & N/A & N/A & N/A & N/A & N/A \\
\hline
\end{tabular}


12 APPENDIX E FUNCTIONAL POINTS OF CONTACT

\begin{tabular}{|c|c|c|c|c|c|c|c|}
\hline \multirow{2}{*}{$\begin{array}{l}\text { Product } \\
\text { Peoplesoft }\end{array}$} & \multirow{2}{*}{$\begin{array}{l}\text { H2K Process } \\
\text { Financial }\end{array}$} & \multicolumn{2}{|c|}{ H2K Functional POC } & \multicolumn{2}{|c|}{$\begin{array}{l}\text { Business Owner } \\
\text { POC }\end{array}$} & \multicolumn{2}{|c|}{ Business Owner } \\
\hline & & Paul Felts & $376-0367$ & Kevin Adamson & $376-6967$ & Roger Corless & $376-8219$ \\
\hline & Payroll & $\begin{array}{l}\text { Didi Staudacher } \\
\text { Pam Edwards }\end{array}$ & $\begin{array}{c}376-2346 \\
376-7175 \\
\end{array}$ & Todd Beyers & $376-2815$ & Mike Byrd & $376-1596$ \\
\hline & Base Benefits & $\begin{array}{l}\text { Becky Calapristi } \\
\text { Pam Edwards }\end{array}$ & $\begin{array}{l}376-7946 \\
376-7175\end{array}$ & $\begin{array}{l}\text { Dorothy Hansen } \\
\text { Harry Lacher }\end{array}$ & $\begin{array}{l}376-8180 \\
376-7156\end{array}$ & Gordon Beecher & $372-8234$ \\
\hline & HR & $\begin{array}{l}\text { Becky Calapristi } \\
\text { Pam Edwards }\end{array}$ & $\begin{array}{l}376-7946 \\
376-7175 \\
\end{array}$ & $\begin{array}{l}\text { Dorothy Hansen } \\
\text { Harry Lacher }\end{array}$ & $\begin{array}{l}376-8180 \\
376-7156\end{array}$ & Gordon Beecher & $372-8234$ \\
\hline & Training & $\begin{array}{l}\text { Lucy Reed } \\
\text { Pam Edwards }\end{array}$ & $\begin{array}{l}372-2407 \\
376-7175 \\
\end{array}$ & Joann Brown & $372-0167$ & Jim Gamin & $376-1910$ \\
\hline \multirow[t]{4}{*}{ PassPort } & Supply - Inventory & $\begin{array}{l}\text { Shari Bultena } \\
\text { Chris Hopkins }\end{array}$ & $\begin{array}{l}376-4034 \\
376-3275\end{array}$ & $\begin{array}{l}\text { Dick Boehning } \\
\text { Bill Laughery }\end{array}$ & $\begin{array}{l}373-4036 \\
376-1557\end{array}$ & Kirk Higgenson & $372-2503$ \\
\hline & $\begin{array}{l}\text { Supply - Purchasing \& } \\
\text { Contracts Module }\end{array}$ & $\begin{array}{l}\text { Kim Schultz } \\
\text { Chris Hopkins }\end{array}$ & $\begin{array}{l}376-0466 \\
376-3275 \\
\end{array}$ & Mike Taylor & $376-6483$ & Pat Marmo & $376-1383$ \\
\hline & $\begin{array}{l}\text { Supply-Accounts } \\
\text { Payable }\end{array}$ & $\begin{array}{l}\text { Brent Wagner } \\
\text { Chris Hopkins }\end{array}$ & $\begin{array}{l}372-3620 \\
376-3275\end{array}$ & Debbie Long & $376-6262$ & Mike Byrd & $376-1596$ \\
\hline & $\begin{array}{l}\text { Chemical Management / } \\
\text { MSDS }\end{array}$ & Ken Jaten & $373-9027$ & Mike Stephenson & $376-3870$ & Mike Stephenson & $376-3870$ \\
\hline
\end{tabular}


HANDI 2000

DOC ITEM: DRAFT End User Support Plan

DATE: $7 / 17 / 98$

\section{APPENDIX F REQUIRED ACCESS TRAINING}

\section{Required Access Training}

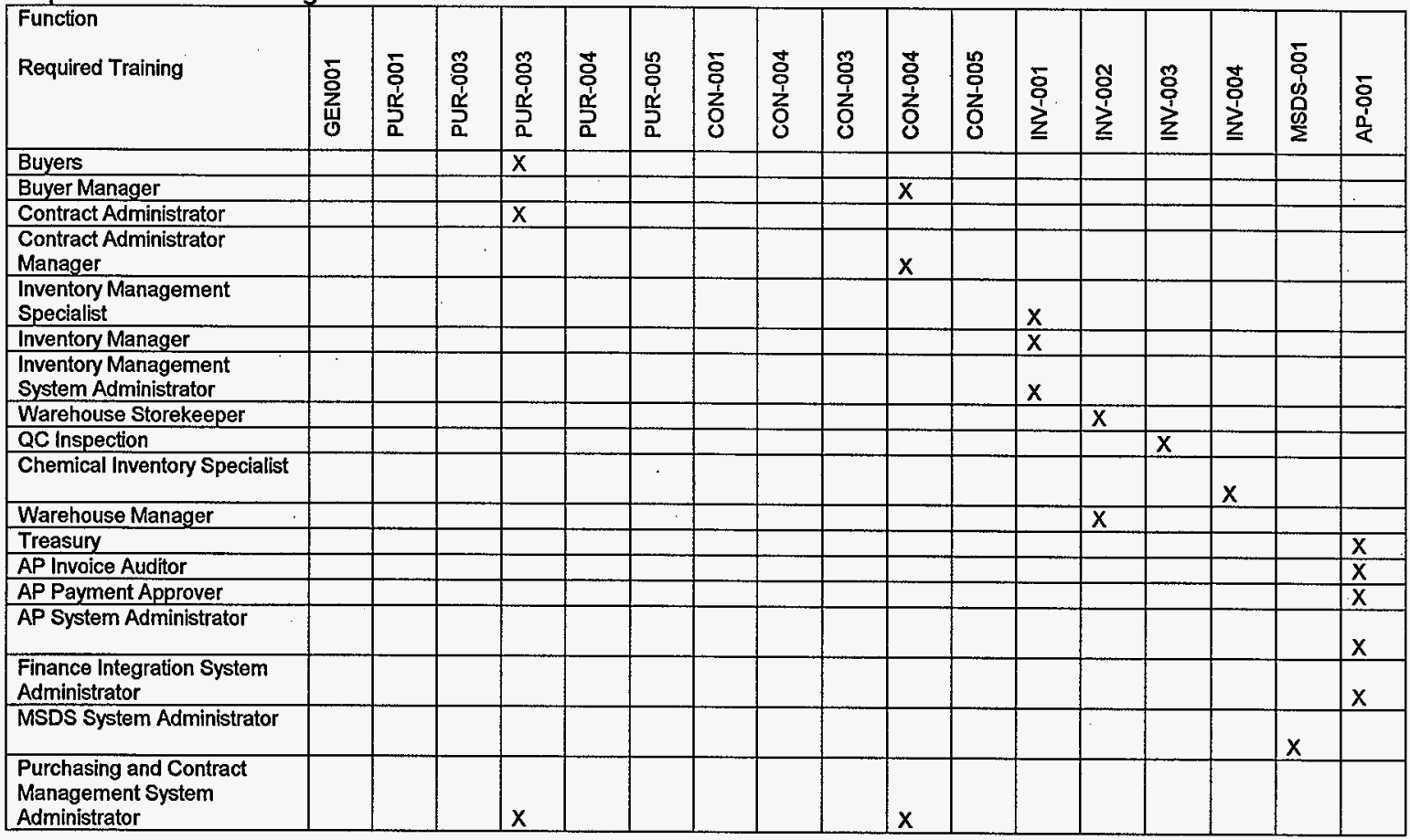

